\title{
DARWINISMUS A EKOLOGICKY UŠLECHTILÍ DIVOŠI
}

\author{
MARTIN SOUKUP
}

\section{Úvod}

Předmětem této studie je analýza možných důsledků současné teorie biologické evoluce pro koncepce ochrany biodiverzity. V úvahu se při zkoumání této otázky musí vzít také antropologické poznatky o kulturách tzv. prrírodních národů. Jejich příslušníci jsou v odborné literatuře nezrrídka prezentováni jako „ekologicky ušlechtilí divoši“. Antropologická data tuto vizi vyvracejí, ne vždy tzv. přírodní národy žijí v harmonickém vztahu $\mathrm{k}$ přírodě. Antropologové naopak dokládají, že nelze oprávněně tvrdit, že teprve společnosti euroatlantického bloku založené na svébytné industriální racionalitě způsobují nevratnou destrukci biodiverzity, že se lidé v tomto regionu vlivem rozvoje vědy a techniky jaksi fatálně odklonili od své přirozenosti. Teorie biologické evoluce se zvláštním přihlédnutím ke koncepci tzv. sobeckého genu navíc vede k závěru, že altruistické ochranářské postoje $\mathrm{k}$ biodiverzitě nemohou být součástí lidské přirozenosti. Současně z ní nicméně vyplývá, že sobecké individuální jednání může vyústit v původně nezamýšlenou kooperaci. Znamená to mimo jiné, že navzdory lidské přirozenosti lze zavést programy ochrany biodiverzity, jak ostatně doložíme několika prŕíklady z Nové Guineje. Obecně lze říci, že současné poznatky antropologie a evoluční biologie nás informují, že ochranářské postoje $\mathrm{k}$ biodiverzitě nejsou součástí lidské přirozenosti, ale lze přijmout a naučit se je navzdory lidské přirozenosti. Tato tvrzení nicméně vyžadují podrobnější výklad, kterému se budeme věnovat $\mathrm{v}$ této studii.

Otázkám důsledků darwinistického výkladu lidské přirozenosti pro programy a koncepce ochrany biodiverzity se věnuje spíše okrajová pozornost. Přitom teorie biologické evoluce vycházející ze zakladatelského díla Charlese Darwina představuje dominantní paradigma $v$ prírodních vědách a přináší významné poznatky o původu života na Zemi a jeho rozmanitosti. Pokud se již výše uvedené problematice věnuje pozornost, ne vždy se uznává, že z biologické evoluce nelze odvodit žádný opodstatněný důvod, proč by lidé měli jiným druhům organismů věnovat péči a ochranu, nebo dokonce dbát o zachování biodiverzity [Wachner 2009]. Jinými slovy, z evolučně vzniklého „je“ nelze odvodit „mělo by se “ [Dennett 2008: 77]. ${ }^{1}$ Takové závěry odmítla řada vědců. Mezi jinými lze uvést francouzského environmentalistu Edwarda Goldsmithe (1928-2009) nebo norského filozofa Arneho Naesse (1912-2009), kteří usilovali o sblížení evoluce s žádoucími programy ochrany biodiverzity.

\footnotetext{
Tento axiom jako první formuloval anglický filozof David Hume (1711-1776).
} 
Nezř́ídka se také předpokládá, že takzvané př́rodní národy mohou sloužit jako vzor soužití člověka s prŕrodou [srov. Berkes 1999; Callicott 1994; Krech 1999]. Kolem tohoto názoru se $\mathrm{v}$ posledních letech objevila $\mathrm{v}$ odborném tisku poměrně široká diskuze [Hames 2007; Smith 2000]. Současně zastánci ochrany biodiverzity obviňují euroamerickou civilizaci z toho, že se rozhodujícím způsobem podílí na devastaci biodiverzity do té míry, že se v ohrožení ocitl život na Zemi jako takový. Darwinismus přichází se závěrem, že součástí evolučně formované lidské přirozenosti nemůže být žádný „gen pro ochranu prŕrody“. Obecně lze konstatovat, že biologická evoluce spíše podporuje vyhledávání momentálního individuálního prospěchu, než současnou individuální skromnost, která umožní kvalitní život budoucích populací. Jak se pokusím doložit, kořeny ochranářského přístupu k ekosystémům se musí hledat v kultuře, nikoli v evolučně formované lidské přirozenosti. Ridley $\mathrm{v}$ této souvislosti uvedl, že se hospodárnému zacházení s př́rodními zdroji a ekologické etice musíme učit navzdory lidské přirozenosti, nikoli v souladu s ní [Ridley 2000: 235]. Pokud skutečně vyplývají vztahy lidských populací k ekosystémům z povahy konkrétní kultury, je tedy otázkou zda můžeme zjednodušeně polarizovat a prohlásit takzvané přírodní národy za následováníhodný model a euroamerickou civilizaci naopak za ekologicky patologickou. Že euroamerická civilizace zásadním způsobem přispívá ke snižování biodiverzity a zhoršování podmínek pro život na Zemi, považuji za jednoznačně doložitelné, ale rozhodně se neztotožňuji s romantizující představou „ekologicky ušlechtilých divochü“.

Lze totiž bezpečně doložit, že př́rodní národy nejsou jednoznačně ekologicky ušlechtilými divochy, jak tuto představu pojmenoval Kent Redford [Redford 1990]. Mnozí autoři prokázali, že populace lovců-sběračů v době paleolitu způsobily první velká vymírání a zásadním způsobem narušily ekosystémy. Za mnohé lze uvést devastaci fauny na území Severní Ameriky, Nového Zélandu, Madagaskaru a na mnoha dalších místech [srov. Martin, Klein 1989; Klein, Edgar 2002]. Pokud tedy tvrdíme, že přírodní národy nepřetěžují jimi obývané ekosystémy, domorodce „barvíme nazeleno", jak v této souvislosti poznamenal britský evoluční biolog a popularizátor vědy Matt Ridley [Ridley 2000: 225]. Navíc tato ničím nepodložená idea ekologicky ušlechtilého divocha nezřídka nežádoucím způsobem ovlivňuje programy na ochranu biodiverzity.

Za modelový prríklad lze označit pokus o založení prrírodní rezervace Mbaracayu v jihovýchodní části Paraguaye. Antropologové se na začátku osmdesátých let 20. století pokusili prosadit plán na vytvoření př́rodní rezervace, jejíz správou by byli pověřeni původní obyvatelé regionu, totiž lovci-sběrači kmene Aché a někdejší lovci-sběrači kmene Guaraní, kteří se dnes převážně živí zahrádkařením. ${ }^{2}$ Do projektu se zapojila The Nature Conservancy (dále jen TNC), která se usilovně věnuje ochraně významných ekosystémů v různých oblastech světa. Indiáni Aché a Guaraní, kteří byli dříve z lokality Mbaracayu vyhnáni, vnímali vytvoření rezervace jako př́ležitost domoci se svých přirozených práv $\mathrm{k}$ pralesu. TNC však šlo především o záchranu jednoho z posledních paraguayských nedotčených pralesů. Antropologové usilovali jak o zachování dvou tradičních kultur, tak tím chtěli současně pomoci záchraně pralesa Mbaracayu. Podle nich mohli původní

\footnotetext{
Zahrádkaření (ang. horticulture) je typ výrobního systému. Lidé orientovaní na tento typ subsistence pěstují na svých zahradách zpravidla hlízy, rýži či kukuřici s pomocí jednoduchých technologií. Od zemědělců se odlišují užíváním jednoduchých technologií (ždáření, mýcení, rycí hole).
} 
obyvatelé prospět zejména tím, že velmi dobře znali místní ekosystémy. TNC však umožnila užívání rezervace pouze populacím kmene Aché, které se dosud živí tradičním lovem a sběrem. Pro populace kmene Guaraní, které byly v roce 1971 vyhnány ze svých domovů a musely se začít živit zahrádkařením, nebylo v rezervaci místo. TNC založila rozhodnutí na představě, že existuje ideální „původní stav lidstva“, který je potřeba chránit. Jako kdyby př́rodní národy byly živoucími zkamenělinami. Př́rodní národy kontaminované západní kulturou proto již nejsou „ekologicky ušlechtilými divochy“ [Redford 1990], nýbrž „ekologickými hybridy“ [Reed 2007].

Na základě dostupných antropologických a archeologických dat nelze jednoduše prohlásit, že kultury prírodních národů, at již recentních, nebo minulých, existují v přirozeném souladu s místními ekosystémy, které nepřetěžují, natož aby je devastovaly. Zatím jsme se ovšem nevěnovali otázce, zda lze odvodit z principů biologické evoluce nějakou formu ekologické etiky, nebo poučení pro koncipování programů ochrany biodiverzity.

\section{Darwin a darwinismus}

Darwinismus patří $\mathrm{v}$ přírodních vědách $\mathrm{k}$ nejvýznamnějším teoriím, kterými lze vyložit vývoj a rozmanitost života na Zemi. Jak je obecně dobře známo, položil základy jedné z prvních ucelených teorií biologické evoluce britský př́rodovědec Charles Robert Darwin (1809-1892), když v roce 1859 publikoval dílo On the Origin of Species (O původu druhů). V něm popsal a dokumentoval hlavní principy evoluce druhů organismů. Ačkoli se Darwinova teorie prosazovala relativně pomalu, stala se nakonec ve 20. století dominantní teorií, s jejíž pomocí vědci vysvětlují nejen evoluci života, ale také lidské sociální chování, rozhodování, lidskou mysl a mnoho dalšího. Půvab jeho teorie spočívá i v tom, že jeho výklad rozmanitosti života nepotřebuje žádné zásahy vyšší inteligence, nadpřirozených jevů, nebo procesů. V tom podle amerického filozofa Daniela Dennetta (narozen 1942) spočívá Darwinova nebezpečná myšlenka. Stejný autor zároveň konstatoval, že „kdykoli je tématem darwinismus, tak okamžitě začne stoupat teplota, protože $\mathrm{v}$ sázce je mnohem více, než jen jak se vyvinul život na Zemi..." [Dennett 1995: 21]. V sázce může být např́klad otázka darwinistického výkladu vztahu mezi lidskou přirozeností a ochranou biodiverzity.

Přestože od doby publikování definitivní šesté edice klasického díla O původu druhů uplynulo více než sto let a přirozeně došlo i $\mathrm{k}$ vývoji samotné teorie, zůstávají některé Darwinovy názory na principy evoluce nadále součástí současné teorie biologické evoluce. Podstatu původní Darwinovy teorie lze shrnout do sedmi axiomů:

1. Všechny druhy organismů povstaly evolucí a mají jednoho společného předka. „Pravděpodobně všecky ústrojné bytosti, které kdy žily na této zemi, vznikly z nějaké jediné prapůvodní formy..." [Darwin 1953: 311].

2. V procesu evoluce se druhy organismů proměňuí. „V̌sechny druhy [se] změnily, a změnily se tak, jak má domněnka vyžaduje, nebot se měnily zvolna a plynule“ [Darwin 1953: 300].

3. Proces evoluce se odehrává přirozeně bez zásahu nějaké nadpřirozené síly. „Každý druh nebyl zvlášt stvořen, nýbrž že vznikl jako odrůda z jiného druhu“ [Darwin 1953: 9]. 
4. Jednou z klíčových, ale nikoli jedinou sil evoluce je přirozený výběr. „Jsem přesvědčen, že přírodní výběr byl hlavním, avšak ne jediným z činitelů uzpůsobení “ [Darwin 1953: 11].

5. Přirozený výběr působí na variabilitu dědičných znaků. „Odchylka, která se nedědí, je pro nás nezajímavá“ [Darwin 1953: 15].

6. Evoluce probíhá formou soutěže mezi jedinci druhu a mezi druhy. Darwin přejal pro označení této soutěže označení „boj o život“. „Protože je vytvářeno více jedinců, než kolik jich může přežít, musí zde v každém případě dojít k boji o existenci bud' jednoho jedince s druhým jedincem téhož druhu, nebo s jedinci jiných druhů, nebo s fyzickými podmínkami života“ [Darwin 1953: 49].

7. Hlavními produkty evoluce přirozeným výběrem jsou adaptace a diverzifikace druhů organismů. „Přírodní výběr působí výhradně jen zachováním prospěšných uzpůsobení [Darwin 1953: 119]. „Přírodní výběr téměř nevyhnutelně působí vyhubení méně schopných forem života a vede k tomu, co jsem nazval rozbíhání znaků“ [Darwin 1953: 10].

Darwin se ve svém stěžejním díle opatrně vyhnul otázce evoluce člověka. Naznačil ovšem, že jeho teorie může osvětlit původ a vývoj člověka. Definitivně tak svázal lidský druh se světem přírody a jeho zákony. V evropském myšlení se do té doby dlouhodobě udržovala představa, že člověk je na vrcholu bytí a je nad přírodou, které vládne. To lze dosvědčit řadou idejí a konceptů v evropském myšlenkovém dědictví. Podle biblické tradice umístil Bůh člověka na vrchol stvoření a svěřil mu vládu nad prrírodou, jak dokládají notoricky známé věty z první knihy Mojžíšovy. Oddělenost člověka od prrírody vyjadřovala také jednorozměrná koncepce scala naturoe, „řetězce bytí'. Jedná se o ideu, která vznikla již v antice a má původ v myšlenkách antických filosofů Platona (427-347 př. n. 1.) a Aristotela ze Stageiry (384-322 př. n. 1.). Podstatou ideje řetězce bytí je seřazení existujících entit v nám známém univerzu na škále od nejvyšší po nejnižší. Nejvyšší místo náleželo Bohu a nejnižší nerostům. Každá entita byla určena pozicí „vyšší než“ a „nižší než“ [Lovejoy 1964]. Kromě toho můžeme odkázat na vývoj novověké vědy v 16. a 17. století, kdy se vyostřila mocenská pozice člověka vưči př́rodě. Nejčastěji se v této souvislosti odkazuje na anglického teoretika vědy Francise Bacona (1561-1626), který proklamoval, že přírodu musí lidé násilím přinutit, aby vydala svá tajemství [Hadot 2010]. Na počátku 17. století se také zrodil kartezianizmus, kterému představitelé filozofie a environmentalismu kladli k tíži, že stojí u zrodu bezuzdné exploatace prŕírody. Příčinu kritici spatřují v tom, že René Descartes odlišil res extensa a res cogitans, tedy substanci myslící, která se zásadně odlišuje od substancí rozprostraněných. Descartes přisoudil res cogitans pouze člověku. Všechny organismy považoval za stroje, které mohou lidé ovládat, zkoumat, využívat [Descartes 1970]. Kromě člověka nedisponují organismy duchem, proto netrpí. Založil tím další koncepci dualismu duše a těla a umožnil tak ideologické zdůvodnění vědeckých výzkumů, které zkoumají netrpící přírodu všemi dostupnými prostředky.

Tendence $\mathrm{k}$ reintegraci člověka do prrírody existovala v evropském vědeckém myšlení nejméně od 18. století, kdy například švédský botanik Carl Linné (1707-1778) zařadil člověka mezi primáty, když navrhl nové principy taxonomie, jejíž základy položil v díle Systema Naturce (Soustava přírody, 1735), v němž právě zařadil člověka do řádu primátů. Zásadní krok k podřazení člověka přírodním zákonům však znamenala až Darwinova te- 
orie biologické evoluce. Člověk je podle darwinismu jedním z mnoha druhů organismů, který se vyvinul na základě stejných principů jako každý jiný druh. Darwinův svět je nejen světem bez zázraků, ale také světem vnitrodruhové a mezidruhové konkurence, které představují hybnou sílu evoluce. Již takto popsaný svět nevytváří prostor pro ochranářské postoje k prŕrodě. Nad těmito důsledky své teorie se přirozeně Darwin nezamýšlel, protože otázkami ochrany biodiverzity se začali vědci a filozofové intenzivně zabývat až v druhé polovině 20. století. Nicméně již na začátku 20. století vznesl ruský kníže Petr Alexejevič Kropotkin (1842-1921) kritiku Darwinovy představy evoluce života na principu konkurence. Stalo se tak v jeho jediném darwinistickém díle Mutual Aid (Vzájemná pomoc, 1905), do nějž se silně promítly jeho politické a sociální názory. V této práci na naivních antropomorfizovaných příkladech ze života zvířat argumentuje, že „vedle zákona o vzájemném boji jest v přírodě i zákon o pospolitosti, který jest pro úspěšný zápas o život a zvláště pro postupný vývoj druhu mnohem důležitější než zákon vzájemného boje“ [Kropotkin 1922: 9]. Vzájemná pomoc mezi jedinci téhož druhu pomáhá podle Kropotkina přežívání i takových druhů, jejichž jedinci by jinak sami neobstáli. Tvrdil totiž, že

kdyby byl vývoj živočišné říše založen výlučně, nebo v prvé řadě na tom, že nejschopnější předrží období zlá, kdyby se př́rodní výběr omezoval jen na období výjimečných such, nebo náhlých změn teploty či povodní, pak by živočišný svět upadl. Ti, kdož předrží hlad, nebo hroznou nákazu cholerou, nebo neštovice, nebo záškrt, jak to vídáme v necivilisovaných krajích, nejsou ani nejsilnější, ani nejzdravější, ani nejinteligentnější. Na těchto nelze stavěti pokrok... [Kropotkin 1922: 66]

Kropotkin zdůraznil, že spolupráce sehrála důležitou roli v evoluci člověka a jeho dějinách. Spolupráce byla nezbytností, protože „tvor, tak bezbranný... “ by nemohl přežít, kdyby žil „,v nemilosrdném zápasu o výhody osobní, aniž by dbal zájmů druhu“ (Kropotkin 1922: 77).

V jistém smyslu dala evoluční biologie ve 20. století Kropotkinovi za pravdu. Rozvoj evoluční biologie ve druhé polovině 20. století vyústil v takzvanou genocentrickou revoluci, kterou vyvolal svými teoretickými názory americký evoluční biolog George Christopher Williams (1926-2010) a podíleli se na ní i vědci jako Robert Trivers (narozen 1943) a William Donald Hamilton (1936-2000). Podstatou genocentrické revoluce je změna subjektu biologické evoluce, kdy se evoluční procesy vysvětlují na úrovni genů, nikoli organismů. Podle evolučních biologů jsou organické struktury výsledkem soutěže mezi alelami, a nikoli mezi jedinci nebo druhy. Známější se tato nová teorie stala pod označením sobecký gen, které zavedl britský evoluční biolog Richard Dawkins (narozen 1941). Ten popularizoval Williamsovy názory v práci The Selfish Gene (Sobecký gen, 1976). Centrálním pilírem této knihy se stal výklad biodiverzity a sociálního chování prostřednictvím evoluce genů. O tom svědčí jeho následující slova: „Budu se snažit dokázat, že základní jednotkou selekce, a tedy i starosti o sebe sama, není ani druh, ani skupina, dokonce ani jedinec. Je jí gen, jednotka dědičnosti“ [Dawkins 1998: 21]. Tato radikální změna perspektivy vedla $\mathrm{k}$ dalšímu rozvoji teorie biologické evoluce a podnítila i celou řadu výzkumů v nejrůznějších oblastech. Tyto teoretické názory se tak staly východiskem i pro výklad biologických základů altruismu. Podíl na tom má především výše uvedený americký evoluční biolog Robert Trivers. 
Ten ve studii The Evolution of Reciprocal Altruism (Evoluce recipročního altruismu, 1971) rozpracoval model evoluce altruismu mezi nepř́ibuznými jedinci téhož druhu. $\mathrm{Za}$ určitých podmínek může přirozený výběr favorizovat altruistické chování, protože může v dlouhodobé perspektivě přinášet genům výhody. Zkrátka řečeno, „modely, které se pokoušejí vysvětlit altruistické chování v pojmech přirozeného výběru, jsou navrženy tak, že altruismus zbavují všeho altruismu" [Trivers 1971: 35]. Pro altruistické chování v podmínkách přirozeného výběru je typické, že ztráta dávajícího je nižší než zisk obdarovaného. Např́íklad pro sytého je darování krajíce chleba zanedbatelná ztráta, ale pro hladového mủže krajíc chleba znamenat přežití. Aby se mohl rozvinout biologicky determinovaný reciproční altruismus, musí se mezi zúčastněnými stranami uskutečňovat transakce s nenulovým součtem. Každá strana musí nakonec dosahovat nějakého zisku; zisk jedné strany nesmí být na úkor strany druhé. Musí také existovat mechanismy, které umožní identifikovat a potrestat potenciální černé pasažéry, kteří by jinak parazitovali na altruismu druhých. Trivers dokázal, že takové podmínky jsou z hlediska evoluční teorie nejen možné, ale došlo i k jejich evoluci. Ve svých úvahách věnoval pozornost i recipročnímu altruismu mezi lidmi. Konstatuje, že se ve všech lidských kulturách můžeme setkat $\mathrm{s}$ následujícími typy altruismu: pomoc $\mathrm{v}$ době nebezpečí, sdílení potravy, pomoc v době nemoci, dětství a stárí, sdílení nástrojů a znalostí [Trivers 1971]. Kropotkinovi tedy evoluční biologové dali v jistém smyslu za pravdu, když ukázali, že evoluce se může uskutečňovat i ve formě spolupráce a altruismu. Kooperace a altruismus se ovšem nezakládají na „zákoně spolupráce“, ale jsou výsledkem sobeckého jednání.

\section{Důsledky darwinismu pro ochranu biodiverzity}

Podíváme-li se optikou „sobeckého genu“ na snahy o ochranu biodiverzity, snadno dojdeme $\mathrm{k}$ závěru, že pro ně neexistuje $\mathrm{v}$ lidské přirozenosti žádná opora. Velmi zjednodušeně řečeno, nenajdeme $\mathrm{v}$ lidském genofondu gen, který by nás vedl $\mathrm{k}$ chování za účelem ochrany biodiverzity. Důvodů existuje hned několik. Je velmi nepravděpodobné, že by mohla nastat evoluce genu, který by podporoval evoluci genů v genofondu veškerých jiných druhů organismů. Biologická evoluce je proces, který je založen na náhodě, není plánovitý. Nemá jiný cíl, než úspěšnou a maximální reprodukci žijících organismů, nikoli organismů $\mathrm{v}$ budoucnu. Jinými slovy, biologická evoluce je proces, který se odehrává $\mathrm{v}$ současnosti a nestará se o minulost, natož o budoucnost. Zda dojde $\mathrm{v}$ budoucnosti k zásadnímu zhoršení podmínek pro život na Zemi, $\mathrm{k}$ výraznému snížení biodiverzity, nebo dokonce $\mathrm{k}$ jejímu zániku, vůbec není pro reprodukci v současnosti rozhodující.

Teorie takzvaného sobeckého genu má také kulturní důsledky v tom, že umožňuje ideologicky zdůvodnit lidské destruktivní chování. Jestliže totiž hlavní činitele biologické evoluce již nepředstavují jedinci, ale geny, tedy slepé determinující síly, má tato skutečnost zásadní důsledky pro programy ochrany biodiverzity. Tento posun $\mathrm{v}$ teorii biologické evoluci totiž umožňuje sejmout $\mathrm{z}$ lidí odpovědnost za současné jednání a jeho důsledky pro budoucnost. Bytost, která je řízena nevědomými a zděděnými silami $\mathrm{v}$ sobě, nemůže být volána $\mathrm{k}$ odpovědnosti. Přijetí takového paradigmatu by mohlo vést $\mathrm{k}$ závěru, že nelze vystavět a úspěšně uplatnit žádnou koncepce environmentální odpovědnosti. 
Mýty o „ušlechtilém divochovi“, který žije v souladu s přírodou, byly již mnoha autory přesvědčivě vyvráceny. Jak jsem konstatoval, vědci opakovaně doložili, že už lidé v době paleolitu zpo̊sobili ekologické katastrofy, vybíjeli zvěř a zpo̊sobili vymírání některých druhů organismů. Mýtus o ušlechtilém divochu žije vlastním životem a podporuje sebemrskačství Západu, který sám sebe volá k odpovědnosti za škody zpơsobené na biodiverzitě. Za hlavního viníka zániku biodiverzity se všeobecně považuje člověk, jehož chování a kulturu zvláště považují mnozí za nepřirozené. Podíváme-li se na člověka optikou biologické evoluce, je zjevné, že se člověk chová zcela přirozeně a v souladu s principy biologické evoluce.

Např́klad americký evoluční biolog Richard Lewontin (narozen 1929) konstatoval, že každý druh organismu přetváří svými životními pochody prostředí, které obývá. Lidské populace nejsou výjimkou, přijímají ze svého okolí to, co potřebují, a vylučují škodlivé. Rozdíl je snad pouze $\mathrm{v}$ tom, že Homo sapiens je nejúspěšnější druh organismu v nám známých dějinách života na Zemi. V důsledku to znamená, že čím je nás více, tím rychlejší a dramatičtější jsou dopady našeho přetváření světa. Uvedený Lewontin dovozuje, že neexistuje žádné prostředí, které by bylo vůbec možné chránit. Prostředí utvářejí druhy organismů a každý z nich nepřetržitě přetváří prostředí, nejen lidé. Neexistuje tedy žádný stav, který by bylo lze chránit. Neobstojí ani výzva „zabraňme vymírání druhů organismů!“. Druhy organismů zanikají nepřetržitě a všechny druhy organismů jednou zaniknou, nejpozději se zánikem Slunce. Podle Lewontina je život na Zemi tak jako tak již za polovinou možného trvání své existence [Lewontin 2000: 68].

Otázkou vymírání druhů se zabýval např́iklad americký paleontolog David Malcom Raup (narozen 1933). Ten doložil, že většina druhů organismů, které kdy na Zemi žily, již vyhynula. Planeta Země není sama o sobě nejbezpečnějším místem pro život. Vyslovil rovněž smysluplný názor, že vymírání druhů organismů stimuluje biodiverzitu. Bez vymírání by došlo k nasycení biodiverzity do té míry, že by se zastavila speciace. Naopak vymírání biodiverzitu podporuje. Doslova napsal:

Vymírání, alespoň v našem světě, neustále poskytuje nové možnosti různým organismům, které tak mohou pronikat do nových prostředí a způsobů života. Tento proces udržuje dynamiku evoluce a snad je nutný pro dosažení různosti forem života, minulých i současných. [Raup 1995: 23-24]

Lidské populace jsou jistě katalyzátorem vymírání druhů a snižování biodiverzity, ale biodiverzita existuje do chvíle, kdy žijí alespoň dva druhy organismů (nezvažuji vnitrodruhovou rozmanitost). Lze ovšem důvodně předpokládat, že pokud by došlo k radikálnímu vymírání druhů organismů vlivem člověka až na limitu dvou, pak by pravděpodobně Homo sapiens nebyl jedním z přeživších. Biodiverzita by pak mohla opět postupně narůstat bez lidského faktoru.

Z hlediska biologické evoluce by se stejně těžko prosazovala individuální skromnost ve prospěch všech. Přesvědčivě to dokládá teorie her, která se stala jedním z gnoseologických nástrojů evoluční biologie. Vychází z analýzy ekonomie chování jedinců, kteří nemají kompletní informace o chování dalších účastníků transakce. Hlavním poznatkem plynoucím z teorie her je, že výsledek interakce závisí především na rozhodování všech hráčů. Teorie her posloužila například při výkladu problematiky obecních past- 
vin. Otázkou se zabýval americký ekolog Garrett James Hardin (1915-2003), který v této souvislosti hovořil o „tragédii obecních statků“. Jestliže budou k dispozici zdarma statky, které nikdo nevlastní, hrozí jejich kolaps. Jedinec, který se při využívání takových prostředků, uskromní, na tom nebude v budoucnosti lépe, protože se jeho zmeškané příležitosti chopí někdo jiný. Hardin to přiblížil příkladem obecní pastviny, které využívají různí pastevci. Čím větší je stádo každého pastevce, tím větší výnos z nich má, proto má každý pastevec tendenci zvyšovat velikost svého stáda. Tím dochází k takovému přetěžování pastvin, že dochází k úplnému vypasení trávy a tedy i ke snižování výnosů ze stád. To vše může vést až k úplnému kolapsu [srov. Hardin 1968]. Hardin tak formuloval tezi, že ničím neomezený přístup k limitovaným zdrojům může vést ke kolapsu. Jak vysvětlil rybář Jonathanovi Gulliblovi v př́bězích od Kena Schoollanda, ryby, které patří všem, ve skutečnosti nepatří nikomu, a proto bylo jezero téměř vylovené a zbývající ryby malé [Schoolland 1999]. S nadsázkou lze tedy říci, že francouzský filozof Jean Jacques Rousseau (1712-1778) neměl pravdu, když zastával názor, že kořenem všeho zla ve společnosti je vlastnictví, které můžeme chápat jako regulaci přístupu ke zdrojům pomocí stanovených pravidel. Výzkumy v oblasti teorie her totiž prokázaly, že za určitých podmínek mohou vést opakované transakce vést účastníky $\mathrm{k}$ přijetí pravidel vzájemně výhodné spolupráce na základě skupinové zkušenosti [srov. Peregrin 2011]. Americký filozof Francis Fukuyama (narozen 1952) v této souvislosti hovoří o spolupráci v zájmu soutěže, která může vést k sebeorganizačnímu chování. Takové modely interakcí ilustroval řadou př́kladů, kdy živelně vznikaly normy spolupráce, které jim umožňují překonat rizika spjatá s užíváním společných zdrojů. Tak např́íklad popsal fenomén sluggingu na předměstí Washingtonu. Oficiální místa vyhradila jeden pruh dálnice pro auta s alespoň třemi pasažéry. Díky tomu se urychlil v dobách dopravní špičky přesun lidí do města, nebot̉ nezůstávali uvězněni v kolonách. Obyvatelé na to reagovali postupným rozvojem organizovaného obsazování aut, kdy jedno místo na předměstí sloužilo jako shromaždiště lidí, kterým postupně zastavovala kolemjedoucí auta. Vytvořil se i systém nepsaných pravidel pro obsazování aut a normy pro chování během jízdy [Fukuyama 2006].

Živelně vzniklé normy spolupráce umožňují stabilní způsob sdílení zdrojů, který ovšem vzniká z individuálního sobeckého zájmu. Americká ekonomka Elinor Ostrom (1933-2012) shromáždila a analyzovala tisíce prríkladů využívání společných zdrojů a dokázala, že tyto mohou být efektivně spravovány samotnými uživateli a není vůbec třeba zásahu nebo regulaci zvenčí [Ostrom 1990]. Naopak, pokud dojde k vnějšímu zásahu do pravidel dělby sdílených zdrojů např́klad zavedení nějakého technického řešení, může nastat jejich rychlý kolaps. Tak např́klad tradiční balijští zemědělci měli propracovaný systém hospodaření, které bylo založeno na stanovaném systému zavlažování a ponechávání půdy po určitou dobu ladem. Integrální součástí bylo náboženství a chrámy, které regulovaly zavlažování, když určovaly, které hospodářství bude mít v jaký čas k dispozici vláhu. Balijci v sedmdesátých letech 20 . století přistoupili na odborné rady a opustili systém ponechávání půdy po nějakou dobu ladem a začali sázet odolnější druhy rýže. Systém však naneštěstí zkolaboval, když se objevily virové nákazy rýže a nastal nedostatek vody. Ukázalo se, že tradiční systém byl výhodnou kulturní adaptací, nebot zaručoval dostatek vody pro všechny zemědělce. Navíc ponecháváním půdy ladem zemědělci čelili virovým nákazám [Ridley 2000].

Známé jsou i další příklady. Na nedaleké Jávě došlo vlivem zásahu holandské koloniální administrativy k zemědělské involuci, kterou popsal americký antropolog Clifford 
Geertz (1926-2006). Koloniální vláda přijala rozhodnutí, že zemědělci bud’ musí chodit pracovat stanovaný počet dnů v roce na státní pozemky, nebo na jedné pětině vlastních pozemků pěstovat předepsané odrůdy, přičemž výnosy budou patřit státu. Tím došlo k zemědělské involuci, kdy museli zemědělci na svých pozemcích zvýšit intenzitu práce, aby zvýšili výnosy na pozemcích, ale nedocházelo tím ke zvýšení výnosů na hlavu. Jinými slovy, museli na menších pozemcích dosáhnout alespoň stejného výnosu jako před zavedením nařízení [Geertz 1963].

\section{Antropologické poznatky o vztahu kultury a přírody}

Všechny zkoumané případy ukazují, že předpokladem udržitelného využívání zdrojů lidskými populacemi je dlouhodobá skupinová zkušenost v konkrétních lokálních podmínkách. Snad proto nastala v paleolitu velká vymírání druhů zpơsobená člověkem krátce po příchodu lidských populací do dané lokality. Jinými slovy, udržitelné využívání ekosystému nevyplývá z typu subsistečních strategií, nebo typů společnosti, nýbrž je dáno povahou konkrétní kultury. Zatím jsem uvedl důvody, proč antropologové a evoluční biologové zpochybňují mýtus o ušlechtilém divochovi, který žije v souladu s ekosystémy a nepřetěžuje je. Lze ovšem také najít řadu př́kladů, kdy kulturní adaptace nepřetěžují místní ekosystémy a jsou svou povahou udržitelné.

Ilustrativní je kultura novoguinejského kmene Tsembaga-Maring, jejichž výzkumu se věnoval americký kulturní antropolog Roy Rappaport, který na základě svého výzkumu publikoval monografii Pigs for the Ancestors (Prasata pro předky, 1968). Centrem jeho zájmu se stala analýza cyklů válčení, hodování a příslušných rituálů. V dlouhých cyklech se střídala válečná a mírová období, v němž rituální slavnosti kaiko fungovaly jako nástroj udržování křehké rovnováhy mezi růstem lidských populací a ekosystémem, do níž významně zasahovala stáda chovaných vepřů. Rappaport zastával názor, že tento cyklus efektivním způsobem bránil vzniku ekologické katastrofy. Tu by mohly způsobit př́liš velké chovy prasat. Pro chov rostoucího počtu vepřu se totiž musí postupně zvyšovat produkce ze zahrad, jejichž plocha se musí za tím účelem rozšiřovat. To by mohlo vést až k přečerpání přirozených možností místního ekosystému. Taková situace nenastane díky kaiko.

Při rituálních slavnostech kaiko, které trvají přibližně jeden rok, probíhají př́ipravy na novou válku se znepřáteleným kmenem. V př́pravné fázi vesnice hostí potenciální spojence, porazí se téměř všechna prasata, jejichž maso se jak konzumuje v průběhu slavností kaiko, tak redistribuuje mezi spojence. Kaiko představuje manifestaci síly, protože i sami Tsembag-Maringové prohlašují, že „ti, kdo přicházejí na naše kaiko, přicházejí se také připojit k našim bojům“ [Rappaport 1984: 195]. Podle Rappaporta kaiko přináší také informaci o velikosti a hustotě populace dříve, než nastane válčení, které velikost i hustotu populace ovlivní. Rappaport se odvolává na výrok Wynne-Edwardse, když tvrdí, že se lidé shromáždění během oslav podobají „tanečním kreacím komárů a mušek, reji vírníků, ptačím a netopýřím manévrům při hřadování, ptačím, netopýřím, žabím, hmyzím či garnátím chórům“ [Rappaport 1984: 195]. Tsembagové věří, že čím více prasat porazí a sní, tím více je budou jejich předkové podporovat ve válce. V okamžiku, kdy se zvýší pracovní výkon na zahradách na téměř neúnosnou mez, nastane čas kaiko. Zároveň se jedná o kritickou hranici, po jejímž překročená by jinak hrozila ekologická 
katastrofa v důsledku přečerpání zdrojů. Slavnosti kaiko, při nichž se sníží chovy prasat na minimum, tedy představují adaptační mechanismus, kterým se udržuje rovnováha mezi horskými populacemi a ekosystémem.

Nejen tradiční kultury mohou ilustrovat, že kultura a příroda nemusí nutně být v opozici. Lze doložit i příklady dobré praxe, kdy př́íslušníci západní kultury přispívají k zachování biodiverzity ve spolupráci s lokálními kulturami. Za vzor může sloužit komunita Wannang, ve které jsem uskutečnil antropologickou sondu v roce $2009 .{ }^{3}$ Vesnice Wannang se nachází v provincii Madang, distriktu Middle Ramu. Lidé ve Wannangu sami sebe označují jako komunita Wannang podle řeky, u které se nachází jejich vesnice. Nicméně ve vlastním jazyce si říkají Gali. Obecně lze říci, že kultura lidu Gali představuje typickou ukázku kultur nížin východní části ostrova Nové Guineje. Jejich sociální struktura se zakládá na deseti patrilineárních klanech, vzájemně propojených komplikovanými pravidly exogamie. Jejich výklad původu světa a lidí, které jsou synkrezí křestanství a původních náboženských představ, má rozhodující význam pro jejich vztah k místnímu ekosystému. Bůh vytvořil nejen zemi, vody, zvěř, rostliny, stromy a člověka, ale také duchy všeho, co na světě je. Po pádu Babylonské věže Bůh odeslal lidi do všech možných koutů světa, a tak se také ve Wannangu objevili lidé Gali. Současně s pádem věže vzniklo deset klanů lidu Gali, jehož př́slušníkům Bůh svěřil wannangskou zemi a rozdělil ji mezi muže v deseti klanech. Vlastnictví pozemků od té doby přechází z generace na generaci v linii prvorozených synů, kteří mají povinnost se o pozemky starat a sdílet je se svými bratry. Pozemky mohou využívat pro potřeby své i širší rodiny. Vlastnictví pozemků není nikde zaknihováno, ale uloženo v kolektivní paměti. To je ostatně na Papui Nové Guineji obvyklé, jen asi $5 \%$ vlastnických práv k pozemkům je zaknihováno [Sillitoe 2000].

Papua-Nová Guinea je druhý největší exportér tropického dřeva na světě. Podle oficiálních údajů představuje těžba dřeva 9,2\% HDP Papuy-Nové Guineje, přičemž dřevo většinou končí v jedenácti asijských zemích. Osmdesát procent je nicméně určeno pro trhy v Číně, Japonsku a Koreji. Tam se exportují všechny jen trochu vzrostlé stromy. Na Nové Guineji roste více než sto sedmdesát druhů stromů. V různých průmyslových odvětvích se z nich uplatní více než šedesát, mezi jinými kwila (Intsia bijuga), taun (Pometia pinnata) nebo kamarere (Eucalyptus deglupta), který dorůstá výšky až sedmdesát metrů a může mít i dva metry silný kmen [srov. Bolza 1975]. Předtím však musí firmy i stát získat souhlas majitelů pozemků. Stát stanovuje takzvané Forest Management Area (FMA, Oblast lesní správy), tedy lokality, kde bude probíhat těžba dřeva. Vlastník pozemků, které se ve stanovené oblasti nacházejí, je tak může nabídnout státu, aby našel vhodnou těžební společnost. Osudy tropických lesů v oblasti řek Wannang a Ramu nebudou v následujících letech zrovna jednoduché, protože řada vesnic smlouvy $\mathrm{k}$ těžbě dřeva podepsala. Jen v okolí Wanangu tak v následujících letech zmizí devadesát procent stromů, zbylých deset procent je ve vlastnictví lidí kmene Gali, který zatím smlouvu o těžbě nepodepsal.

Je to dáno dvěma faktory. Zaprvé vztahem k př́rodě, který je rámován stranami trojúhelníku, jehož vrcholy tvoří klanový systém, vlastnictví pozemků a přírodní duchové.

3 Rád bych touto cestou poděkoval prof. Vojtěchu Novotnému, CSc., který mi umožnil odcestovat na Papuu-Novou Guineu a uskutečnit antropologické sondy ve třech místních komunitách. Jeho tým v Binatang Research Centre pro mě vytvořil bezpečné a inspirativní zázemí, proto patří díky i všem pracovníkům a spolupracovníkům této instituce. 
Každý klan má na svých pozemcích posvátné místo duchů, které je tabu. Nesmí se navštěvovat, nesmí se obhospodařovat. Pokud někdo tato tabu poruší, může ohrozit nejen své vlastní zdraví nebo dokonce život, ale také život v okolní přírodě. Na těchto místech totiž žijí duchové, kteří jsou spojeni s duchy všech zvířat a rostlin na daném území. Posvátná místa jsou chápána jako důležitá pro život v př́rodě a úzce souvisí i s aktivitami těžařských společností. V představách Gali má totiž všechno na světě svého ducha. Když je nějaké zvíře zabito, nebo pokácen nějaký strom, tak se musí někam přesunout jeho duch. To zajištují právě duchové na posvátném místě, kteří jsou spojeni se všemi duchy na jimi ovládaném území. Proto také nejde prodat nebo vytěžit posvátná místa, protože po jejich zničení by nebylo nic, co by řídilo přesun duchů a zahynulo by tak úplně všechno. Nastal by kolaps univerza. Řada komunit tak sice přistoupila k prodeji svých stromů, ale posvátná místa by se údajně měla navždy zachovat.

Zadruhé má tato komunita alternativu. Většina komunit na Papui-Nové Guineji má minimální př́ležitost k rozvoji. Jistou příležitost vidí právě v těžařských společnostech, ty ovšem většinou zůstanou u slibů, a lokální komunity tak z těžby svého dřeva profitují jen nepatrně. S Wannangem ovšem navázala dlouhodobou spolupráci výzkumná instituce Binatang Research Centre (binatang je výraz z pidginu pro hmyz). Ta pod vedením českého entomologa profesora Vojtěcha Novotného s lidmi z Wanangu dlouhodobě pracuje při výzkumu biodiverzity v tropických lesích. Podmínkou ovšem je zachování místních tropických lesů, které jsou ve vlastnictví příslušníků komunity Wannang. Lidé ve Wanangu tak mají skutečnou alternativu a nemusí se rozhodovat, zda usilovat o zisk finančních prostředků na svůj rozvoj z těžby dřeva, nebo nemít nic. Zapojení příslušníků komunity do výzkumných projektů přináší komunitě žádoucí finanční prostředky na její rozvoj.

Podobné projekty jsou na Papui-Nové Guineji spíše vzácností. Uvést lze ještě oblast př́rodní rezervace YUS v provincii Morobe, která vnikla v roce 2009, a do jejíhož provozu se zapojily lokální komunity. ${ }^{4}$ Jiný projekt zaměřený na zachování biodiverzity se rozběhl ve druhé polovině devadesátých let 20. století v oblasti Crater Mountain, který však neskončil vzhledem $\mathrm{k}$ interkulturním nedorozuměním stoprocentním úspěchem. Americká kulturní antropoložka Paige West prováděla v Crater Mountain terénní výzkum zaměřený na interakce mezi iniciátory projektu a kmenem Gimi, který oblast obývá. Jak konstatovala, není to o těch dobrých a zlých. Došla k závěru, že většinu obdobných iniciativ předem odsuzuje k zániku skutečnost, že jim nepředchází důkladný antropologický výzkum. Ten by odhalil základní kulturní hodnoty a kognitivní model světa místní komunity. Například prŕíslušníci kmene Gimi z Crater Mountain nerozumějí konceptu „ochrana prostředí“ a mají vlastní představy o tom, co znamená „rozvoj“ vlastní komunity, který výměnou za ochranu prostředí očekávají [West 2006]. Tak jako v popsaném paraguayském případě, o němž jsem psal dřive, tedy rozběhu fungujících ochranářských projektů nebrání toliko institucionální, ale i kulturní bariéry.

4 Během pobytu v roce 2009 jsem provedl sondu v komunitě Yawan, která je součástí YUS. V roce 2011 jsem se vrátil do údolí Uruwa v YUS, kde jsem navázal na předchozí pobyt v komunitě Yawan. Výsledky tohoto výzkumu budou publikovány později samostatně. Nicméně podrobnosti o projektu YUS jsou k dispozici na stránkách Sedmé generace [Soukup 2009; Soukup, Hubeňáková 2011]. 


\section{Závěr}

Každý druh organismu bezustání přetváří svět, to lze chápat jako přirozený proces života na Zemi. Již citovaný Lewontin k tomu uvedl:

Stále se hovoří o tom, jak my lidé ničíme životní prostředí, nejsme však jedineční v tom, že naše životní pochody přetvářejí svět, který má zčásti negativní dopad na pokračování našeho života... Organismy ničí nejen svůj svět, ale také svět svých potomků. [Lewontin 1997: 97]

Lidé jsou však jedineční tím, že se nepřizpůsobují přírodě pouze prostřednictvím biologických adaptací, ale disponují kulturou jako nadbiologickým prostředkem adaptace. Evoluce kultury vybavila některé lidské populace rozvinutým technologiemi, které ještě umocňují přetváření světa, a to do té míry, že se ocitl v ohrožení život na Zemi jako takový. Př́slušníci druhu Homo sapiens na druhé straně disponují vědomím času a schopností plánovat do budoucna. To lidem umožňuje překročit základní limit biologické evoluce, která není plánovitá, nemá žádný předem daný směr a cíl. To vůbec umožňuje formulovat, prosazovat a řídit procesy ochrany biodiverzity a trvale udržitelného rozvoje.

Antropologické poznatky dokládají, že míra udržitelného přežití lidských populací v konkrétních ekosystémech se liší od kultury ke kultuře. Dělicí čára neběží mezi typy společností, nebo typy subsistence, nýbrž mezi jednotlivými kulturami. Rozmanité případy efektivní správy společných zdrojů nacházíme jak v kulturách přírodních národů, tak třeba v euroamerické civilizaci. Analýza těchto př́padů naznačuje, že udržitelnost využívání společných zdrojů pramení z interakcí jedinců prosazujících individuální zájmy. Jinými slovy, že spolupráce je výsledkem prosazování sobeckých zájmů. Kořeny takového chování lze hledat v samotných principech evoluce, která je založena na vnitrodruhové a mezidruhové konkurenci. Obecně lze na závěr konstatovat, že ochranářský přístup k biodiverzitě je kulturní jev, který se může objevit v nějaké konkrétní kultuře. Ačkoli se však jedná o kulturní jev, koncipování funkčních a životaschopných projektů na ochranu biodiverzity a udržitelného přežití lidských populací v konkrétních ekosystémech se neobjede bez znalosti lidské přirozenosti formované procesem biologické evoluce.

\section{LITERATURA}

Berkes, Fikret. 2008. Sacred Ecology. New York: Routledge.

Bolza, Eleanor. 1975. Properties and Uses of 175 Timber Species from Papua New Guinea and West Irian. Highett: CSIRO Division of Building Research.

Callicott, Baird. 1994. Earth's Insights. Berkeley: University of California Press.

Darwin, Charles. 1953. O vzniku druhů prírodním výběrem. Praha: Nakladatelství Československé akademie věd.

Dawkins, Richard. 1998. Sobecký gen. Praha: Mladá fronta.

Dennett, Daniel. 1995. Darwin's Dangerous Idea. Evolution and the Meanings of life. New York: Simon \& Schuster.

Dennett, Daniel. 2008. Záhada ludského vedomia. Bratislava: Europa.

Descartes, René. 1970. Úvahy o první filosofii. Praha: Svoboda.

Fukuyama, Francis. 2006. Velký rozvrat. Praha: Academia. 
Geertz, Clifford. 1963. Agricultural Involution. Berkeley: University of California Press.

Hadot, Pierre. 2010. Isidin závoj. Praha: Vyšehrad.

Hames, Raymond. 2007. „The Ecologically Noble Savage Debate.“ Annual Review of Anthropology 36: 177-190.

Hardin, Garrett. 1968. „The Tragedy of the Commons.“ Science 162 (3859): 1243-1248.

Klein, Richard, Edgar Blake. 2002. The Dawn of Human Culture. New York: John Wiley \& Sons, Ltd.

Krech, Shepard. 1999. The Ecological Indian: Myth and History. New York: Norton.

Kropotkin, Petr. 1922. Pospolitost: vzájemná pomoc. Praha: Družstvo kniha.

Lewontin, Richard. 1997. Biologie jako ideologie. Brno: Jota.

Lewontin, Richard. 2000. The Triple Helix. Cambridge: Harvard University Press.

Lovejoy, Arthur. 1964. The Great Chain of Being. Cambridge: Harvard University Press.

Martin, Paul, Richard Klein (eds.). 1989. Quaternary Extinctions. Tucson: University of Arizona Press.

Ostrom, Elinor. 1990. Governing the Commons. Cambridge: Cambridge University Press.

Peregrin, Jaroslav. 2011. Člověk a pravidla. Praha: Dokořán.

Rappaport, Roy. 1984. Pigs for the Ancestors. New Haven: Yale University Press.

Raup, David Malcom. 1995. O zániku druhů. Praha: Nakladatelství Lidové noviny.

Redford, Kent. 1990. „The Ecologically Noble Savage.“ Orion Nature Qarterly 9 (3): 25-29.

Reed, Richard. 2007. „Two Rights Make a Wrong: Indigenous Peoples Versus Environmental Protection Agencies." Pp. 92-99 in Aaron Podolefsky, Peter Brown (eds.). Applaying Cultural Anthropology. New York: McGraw Hill.

Ridley, Matt. 2000. Původ ctnosti. Praha: Portál.

Schoolland, Ken. 1999. Podivuhodná dobrodružství Jonatana Gullibla. Praha: Centrum liberálních studií. Sillitoe, Paul. 2000. Social Change in Melanesia. Cambridge: Cambridge University Press.

Smith, Eric Alden. 2000. „Conservation and Subsistence in Small-Scale Societies." Annual Review of Anthropology 29: 493-524.

Soukup, Martin. 2009. „O stromových klokanech a kmenových lidech.“ Sedmá generace 19 (4): 9-10.

Soukup, Martin, Julie Hubeňáková. 2011. „Jíst, či nejíst stromové klokany?“ Sedmá generace 21 (6): 31-33.

Trivers, Robert. 1971. „The Evolution of reciprocal altruism.“ The Quarterly Review of Biology 46 (1): 35-57.

Wachner, Amelie. 2009. „What use is evolution to environmentalists?“ Ecologist 39 (6): 11-13.

West, Paige. 2006. Conservation Is Our Government Now. Durham: Duke University Press.

\section{SUMMARY}

Object of the paper is the relationship between Darwinism and nature protection in the context of discussion about ecologically noble savages. Main principles of the Darwin's theory of biological evolution are intrascpecific competition and interspecific competition. Author argues that protectionist attitude to the nature can not be the part of the human nature shaped by the biological evolution. In the light of the theory of biological evolution are cooperation and altruism result of the selfish behavior of the individual organisms. Special attention is devoted to the idea of ecologically noble savages. Author illustrates that indigenous peoples are not always protectionists. The dichotomy of ecologically noble savages and ecologically pathological Euro-American civilization he found as false. It is not possible to work out typology of protectionist and non-protectionist cultures consistent with the typology of subsistence or societies. Author concludes that protectionist attitude to the nature rises as a cultural phenomenon, but is necessary to build programs of the nature protection according to the human nature. 